\title{
RESPONSE OF NON-PREDATORY BIRDS TO A SIMULATED SMALL MAMMAL
}

ROBERT W. NERO, Box 14, 1495 St. James Street, Winnipeg, Manitoba. R3H OW9

Our most effective lure for netting Great Gray Owls is an artificial mouse cast out and retrieved with a bait-casting rod and reel. ${ }^{3}$ This "fishing" technique works best on snow in winter when owls are usually hungrier and, hence more responsive. However a few owls have been taken by us with the lure drawn over gravel roads. This particular lure is a good model of a large meadow vole (see Figure 1). In motion it resembles a scurrying vole much more so than any other lures I have seen. Northern Hawk-Owls, Great Horned Owls, Barred Owls and Snowy Owls also have responded to this lure. The ability of Great Gray Owls and Northern Hawk-Owls to come to the lure from great distances is evident of their keen vision. Response to the lure by a Great Gray Owl even when the lure was not in motion suggest a quick perception of the basic characteristics of its usual prey. In this case a Great Gray Owl flew in between three people standing by a car in an attempt to seize the lure which was dangling from the line on the casting rod as we were making preparations to cast for this owl. ${ }^{3}$ An even more astonishing example of this kind of behaviour was observed by George Nykulaik who had a Great Horned Owl fly in and carry off a lure that was hanging from a rod leaning against the side of his car (pers. comm., 1978). More surprising still is the fact that Nykulaik's lure a plastic imitation mouse - was pale blue! If I hadn't seen a photo of the owl sitting on the lure on the side of the road I wouldn't have believed the story. This business of the colour of the lure is an aspect that merits further investigation.

Predatory non-raptors, such as Northern Shrikes and Gray Jays, have occas- ionally responded to an artificial lure or a live mouse. In winter 1982-83, for example, Herb Copland and I observed a Northern Shrike show mild interest in a cast lure, and in February 1984, Robert R. Taylor had a Northern Shrike respond briefly to a similar lure. On 10 February 1984, while Herb was attempting to lure a Great Gray Owl with a live laboratory mouse at Lac du Bonnet, two Gray Jays showed an interest in the mouse, one even hovering over Herb as he knelt in the snow. If he hadn't flinched when he heard wings overhead the Jay would have likely landed on his head. For a short time after Herb left the site, the jays continued to fly about the spot where they had seen the live mouse. Accounts in Bent's Life History series of the carnivorous habits of Gray Jays, and especially a recent report of a Gray Jay preying on a small live mammal, possibly a shrew, show that this species will occasionally take live mammals. ${ }^{2}$ Oddly, we have no observations of Gray Jays responding to our artificial lure though there have been lots of opportunities for them to do so.

On the other hand, the response of non-predatory birds to lures are inexplicable. What is one to make of our observation of a Downy Woodpecker's response to our lure, and Chris Siddle's remarkable observation of a flock of Common and Hoary redpolls responding to a frozen vole cast and retrieved over the snow? ${ }^{4}$ Presumably there is something compelling about a lure moving across the surface of the snow (whether a dead vole, or stuffed vole skin or an artificial lure) that elicits investigative behaviour. Two additional incidents of non-predatory birds responding to a lure provide further examples of this peculiar behaviour. 
near a feeder when I made a cast across soft snow just to straighten out the line prior to taking the outfit out the next day to lure owls. As soon as I started reeling in the lure the sparrows fluttered out from their perches and briefly hovered over the lure as it moved along, but without coming down to it. On the second cast and retrieve there was much less reaction, and on the third, none at all. I was surprised that the House Sparrows reacted to the lure at all because these birds are accustomed to the presence of several red squirrels and one gray squirrel that regularly visit the feeder. On no occasion have I ever observed any response, other than avoidance behaviour, by our sparrows to these mammals.

At Pinawa Bay on Lac Du Bonnet on 5 February 1984, five Black-capped Chickadees showed a strong response to the lure. Herb Copland and I were standing talking to Ray Tuokko at the Tuokko family home; it was $-30^{\circ} \mathrm{C}$, clear and with a slight wind. It was a fine, bright morning and pleasant in the shelter of trees. Blue Jays, chickadees and House Sparrows were all about and vocalizing. About $1120 \mathrm{~h}$. I decided to try the lure on several House Sparrows, but they flew off before I could make a cast. Instead I tossed the lure a short distance on the clean surfacce of the snow-covered road for two nearby chickadees. As soon as the lure was set in motion there was an instant response. Both birds fluttered towards the moving lure, hovering above it and following it as it was reeled in. I cast it out two more times and three additional chickadees came from about 50 feet and reacted in much the same way. We were all astonished to see that the closer the lure came to me, the greater the response of the birds! The birds landed on the road near the lure, in front of me and beside me in their efforts to get close to the lure. The chickadees showed an unmistakable interest in the lure, even darting in towards it in mid-air as I was making a cast. Once the casting rod accidentally struck a chickadee that was fluttering in front of me when I was making a cast. Eventually, I put the rod and lure in the car for we were anxious to get on our way and look for more Great Gray Owls.

I now regret that we did not get Ray Tuokko to take some photos of the responding chickadees, for when we repeated the experiment on a few other occasions in similar circumstance in February 1984, there was practically no response. On 26 February 1984, for example, I cast and retrieved the lure several times near the Tuokko feeder in the prescent of Pine Grosbeaks, Common Redpolls and Black-capped Chickadees. One chickadee flew to a perch closer to the lure, but did not fly down to it, and at one moment a redpoll seemed to vocalize upon first seeing the moving lure. A live laboratory mouse released onto the surface of the snow drew no apparent response.

Further observations of non-predatory birds responding to a simulated small mammal are needed to provide insight into the nature of this phenomenon. Since anyone with a fishing rod and an imitation mouse can test the response of birds, especially at backyard feeders, it is hoped that our brief observations will eventually be supplemented by new accounts of this unusual behaviour.

1 BENT, A.C. 1946. Life histories of North American jays, crows and titmice. U.S. Natl. Mus., Bull. No. 191. 495pp.

${ }^{2}$ LESHER, F and J. Lesher. 1984. Gray Jay takes live mammal. Loon 56:72-73.

${ }^{3}$ NERO, R.W. 1980. The Great Gray Owl; Phantom of the northern forest. Smithsonian Inst. Press, Washington, D.C. $167 \mathrm{pp}$.

${ }^{4}$ NERO, R.W. 1983. Downy Woodpecker shows investigative behaviour to artificial mouse. Blue Jay 41:168

${ }^{5}$ SIDDLE, C. 1984 . Redpolls attracted to a lure. Blue Jay 42:117. 